\title{
The Conidae Family (Snails Producers of Poisons) Associated with the Rocky Intertidal Zone of Acapulco, Mexico*
}

\author{
Rafael Flores-Garza1, Yareni M. Garcia-Moctezuma1, Pedro Flores-Rodríguez1, \\ Jesús E. Michel-Morfín'2, Carmina Torreblanca-Ramírez ${ }^{3}$ \\ ${ }^{1}$ Laboratorio de Ecología Costera y Sustentabilidad, Unidad Académica de Ecología Marina, Universidad \\ Autónoma de Guerrero, Acapulco, Mexico \\ ${ }^{2}$ Departamento de Estudios para el Desarrollo Sustentable de Zonas Costeras, Universidad de Guadalajara, \\ Jalisco, Mexico \\ ${ }^{3}$ Unidad de Ciencias de Desarrollo Regional, Universidad Autónoma de Guerrero, Acapulco, Mexico \\ Email: rfloresgarza@yahoo.com,yareni mgm@yahoo.com.mx,pfloresrodriguez@yahoo.com, \\ michel11012@yahoo.com.mx, carminatorreblanca@yahoo.com.m
}

Received 3 April 2014; revised 4 May 2014; accepted 11 May 2014

Copyright (C) 2014 by authors and Scientific Research Publishing Inc.

This work is licensed under the Creative Commons Attribution International License (CC BY). http://creativecommons.org/licenses/by/4.0/

(c) (i) Open Access

\begin{abstract}
Acapulco, Mexico has a coastline of $62 \mathrm{~km}$ where large areas of rocky substrate inhabited by organisms such as the GASTROPODA Class can be found. Conidae (Fleming, 1822) Family is among the members of this Class, which has been poorly studied in the Mexican Pacific, despite their biomedical potential. This research was carried out in the rocky intertidal of nine sites in Acapulco. The objectives were: 1) Prepare an inventory of species associated with rocky intertidal of Conidae family, 2) examine the composition of the family based on two criteria: a) species richness and b) abundance, 3 ) determine the geographical distribution and 4) analyze the size composition. The unit sampled was $1 \mathrm{~m}^{2}$ and the sampled area was $10 \mathrm{~m}^{2}$ persite. A total of 97 organisms were analyzed, corresponding to two subfamilies, five genera and five species. The Puncticuliinae (Tucker \& Tenorio, 2009) subfamily had higher species richness, abundance and frequency of occurrence. The most abundant and most common species were Harmoniconus nux (Broderip, 1833) and Gladioconus gladiator (Broderip, 1833) both showed regular distribution. The size structure found for Conidae family is similar to what has been reported in other research. For the first time G. gladiator is being reported for the state of Guerrero.
\end{abstract}

\section{Keywords}

Conidae, Acapulco, Poison, Distribution, Rocky Intertidal Zone

*The Conidae Family (snails producers of poisons) associated with the Rocky Intertidal zone of Acapulco, Mexico. 


\section{Introduction}

The rocky coastline has different microenvironmental conditions and is one of the most diverse habitats in the marine environment. The substrate is stable and secure for many organisms, including mollusks [1]. The Gastropoda Class, is well represented in the rocky intertidal. The Conidae family is part of the class Gastropoda. It has been reported that around 500 species belong to this family which are exclusively marine [2]. For the eastern Pacific 53 species have been reported [3].

Cone shells are nocturnal carnivores feeding mainly on mollusks, worms and fish. To capture their prey using a disposable tooth like a harpoon, which injects a poison called conotoxin or conopeptides. The tooth comes from the toxoglossan radula. Species that feed on fish can produce up to 1000 peptides. Cone shells have separate sexes, but no obvious dimorphism between the shells [4]. The shell, a typical cone, is broad at the top of the spiral of the body and tapers gradually to a narrow base at the front [5], the periostracum is generally thin and translucent, but in some species of this family is thick and opaque [6]. The color pattern of the shell is variable, even within a species [7].

The Conidae family is distributed mainly in the tropical zone of all oceans, most of this family is found in the Indo-Pacific and Western Pacific [5]. Inhabiting different bottom types, including rocky areas, and are found from the intertidal zone to depths greater than $1000 \mathrm{~m}$ [7].

An important feature of the family is its poison, because it is very powerful, even capable of causing death in humans. This poison is a peptide neurotoxin used to neurophysiological studies, this toxin also has a high specificity and a high potential for being synthesized chemically. There are a number of potential pharmaceutical products being derived from conotoxins. These products are being tested to attend diseases such as attention deficit disorder, depression and schizophrenia [8].

Most of the Transitional Mexican Pacific mollusk reports analyze the taxonomic and ecological aspects. In these reports the Cone shells as part of groups that are analyzed are included. Among these reports are those of [9]-[13]. For the coasts of Guerrero there are reports as of [14]-[21].

In the Mexican Pacific Transitional only reports [22] [23], try exclusively in the family Conidae the ecological aspect.

This research was carried out in the rocky intertidal of nine sites in Acapulco, Mexico. Objectives were: 1) Make a list of the species of the Conidae family, associated with rocky intertidal zone, 2) know the composition of the family based on two criteria: a) species richness and b) abundances, 3) determine the distribution sites and 4) analyze the size composition.

\section{Methodology}

\subsection{Study Area}

Acapulco is located in the southern state of Guerrero (latitude $16^{\circ} 41^{\prime}$ and $17^{\circ} 13^{\prime}$ and longitude $99^{\circ} 32^{\prime}$ and $99^{\circ} 58^{\prime}$ ) and has a coastline of $62 \mathrm{~km}$. The average annual temperature is $29^{\circ} \mathrm{C}$ and the weather is warm, sub-humid, with rains from May to November (Gobiernodel Estado de Guerrero, 2005). Sampling was carried out at nine sites which were: Pie de la Cuesta, La Angosta, Parque de la Reina, Muelle, Tlacopanocha, Manzanillo, Palmitas, Enamorados y Majahua (Figure 1).

Each site was georeferenced and described according to the following criteria: approximate length of the sampling area, substrate structure, rock type, wave exposure and substrate stability. Collecting sites were described based on [24], geological maps of the National Institute of Statistics, Geography and Informatics INEGI (Instituto Nacional de Estadística, Geográfica e Informática, Acapulco E14-11, 1:50,000) and observations made in the sampling sites.

The sites vary in type and substrate stability and wave intensity. Substrate types were classified as: a) Massif rocks: fixed structures such as walls, cliffs, terraces, etc., b) Blocks: loose rock larger than $50 \mathrm{~cm}$ in diameter, made of submerged and immovable rocks or that are difficult to move about by the impact of waves, c) Boulders: loose rock of size less than 50 and greater than $8 \mathrm{~cm}$ in diameter, rocks that can be easily moved by the impact of waves, d) Gravel: loose rock no more than $8 \mathrm{~cm}$ in diameter. The stability of the substrate was classified as: a) High: when the substrate remains virtually unchanged by the impact of waves, b) Middle: when the impact of the waves does not change the configuration of the substrate but there is rock movement, c) Low: when the site configuration changes by the impact of waves, most of the rocks are moved. The wave exposure was classified 


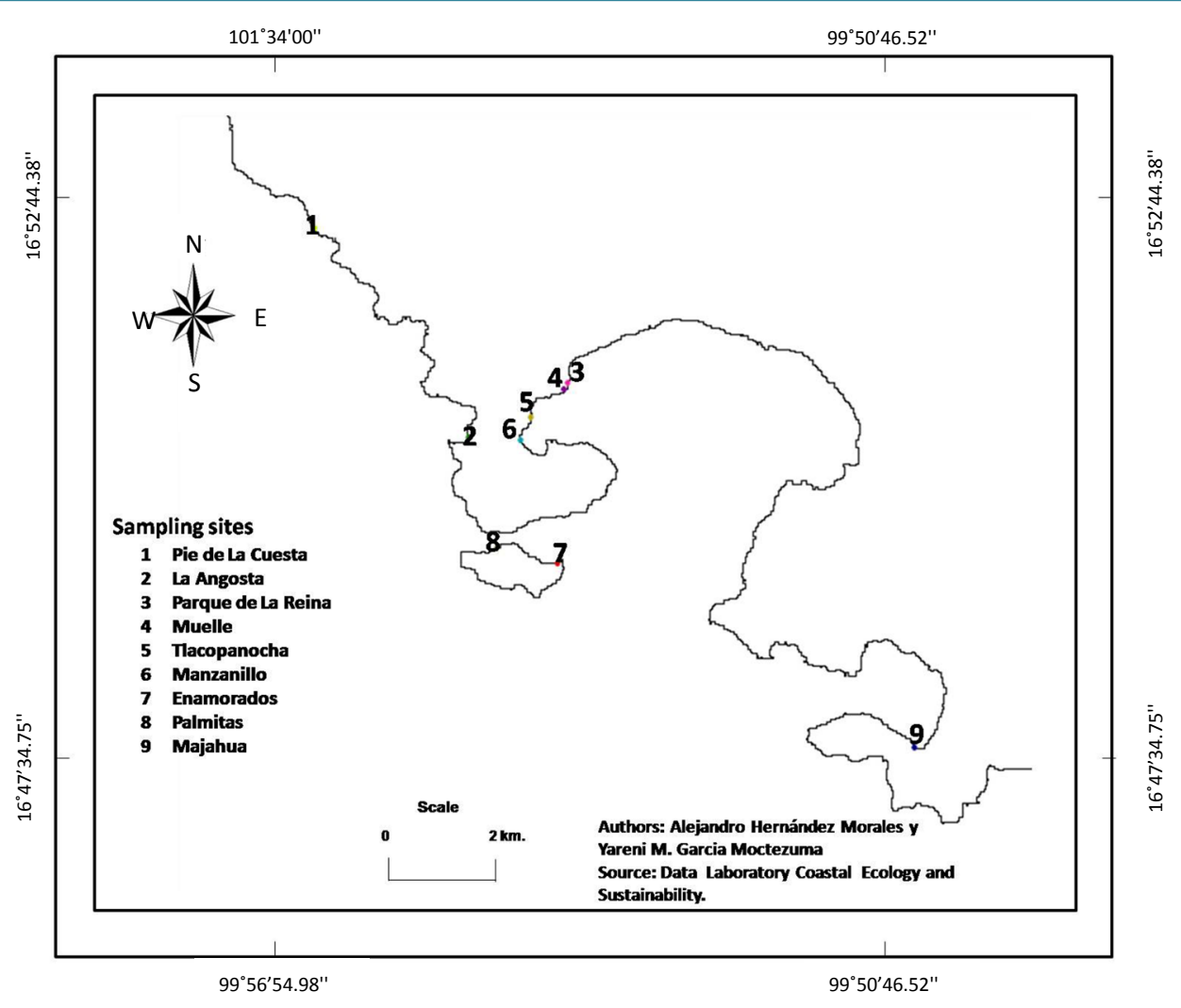

Figure 1. Location of sampling sites in Acapulco.

as: a) High: when the wave hits the substrate in a free manner, usually the sites that have this type of waves are outside from the protection of barriers such as bays or hooks, b) Middle: when the impact of the wave on the substrate is hindered by barriers or smoothing, as can occur at sites that are in front of the entrance of bays or at a distance from a wall of hooks, it also happens in places where subtidal rocky substrate merges or is shallow and reduces the direct impact of the waves to the substrate, c) Low: when the wave does not directly hit the substrate, since the sites are protected by different types of barriers [25] (Table 1).

\subsection{Field Methodology and Data Analysis}

In February and March 2009 to 2012, an annual sampling was conducted for each site. Sampling was performed during the hours of low tide at new moon days. To carry on the quantification of organisms an area of $10 \mathrm{~m}^{2}$ was sampled per site. Sampling was systematic. The starting point was randomly selected and then a nylon rope 30 $\mathrm{m}$ long was placed parallel to the shore on the intertidal zone using a PVC pipe square frame $1 \mathrm{~m}$ per side to delimit the sampling unit. Once the starting point was established, the PVC frame was placed at the selected point. All Conidae specimens found alive, even those attached under rocks within the sampling unit, were collected and placed into a plastic container filled with seawater and protected from direct sunlight. After completing the collection, a $2 \mathrm{~m}$ intersection along the rope was measured then the frame was positioned again to define the following sampling unit. This procedure was repeated ten times along the nylon rope.

The specimens were placed in bottles containing $96 \%$ ethyl alcohol and taken to the laboratory to be identified and quantified. The identification of specimens and the update of the nomenclature, required a confirmation step in the laboratory, using literature such as [3] [5].

The collected specimens were measured in length and width (mm).

Species richness was assessed based on the number of species found in the samples. Relative abundance was measured as the percentage of each species with respect to the total number of specimens. The type of geographic distribution was evaluated using on the frequency of occurrence of species per site as follows: wide (frequency of 7 - 9 sites) regular (frequency of 4 - 6 sites) and irregular (frequency of 1 to 3 sites). 
Table 1. Geographical location of sampling sites and major characteristics of he rocky intertidal habitat in Acapulco, Mexico.

\begin{tabular}{|c|c|c|c|c|c|c|c|c|}
\hline & \multirow{2}{*}{ Site } & \multicolumn{2}{|c|}{ Coordinates } & \multirow{2}{*}{ Size of thesite. } & \multirow{2}{*}{ Type of Substrate } & \multirow{2}{*}{ Type of Rock } & \multirow{2}{*}{$\begin{array}{c}\text { Substrate } \\
\text { stability }\end{array}$} & \multirow{2}{*}{\begin{tabular}{r|} 
Wave \\
exposure
\end{tabular}} \\
\hline & & Latitude & Longitude & & & & & \\
\hline 1 & Pie de la Cuesta & $16^{\circ} 52 ' 25.64^{\prime \prime}$ & $99^{\circ} 56^{\prime} 34.64^{\prime \prime}$ & $66 \mathrm{~m}$. & $\begin{array}{l}\text { Massif rocks } \\
\text { and blocks }\end{array}$ & Metamorphic & High & High \\
\hline 2 & La Angosta & $16^{\circ} 60^{\prime} 29.86^{\prime \prime}$ & $99^{\circ} 54^{\prime} 55.70^{\prime \prime}$ & $48.14 \mathrm{~m}$. & $\begin{array}{l}\text { Massif rocks } \\
\text { and Boulders }\end{array}$ & Metamorphic & High & High \\
\hline 3 & $\begin{array}{l}\text { Parque de } \\
\text { la Reina }\end{array}$ & $16^{\circ} 51^{\prime} 01.21^{\prime \prime}$ & $99^{\circ} 54^{\prime} 02.04 "$ & $66.74 \mathrm{~m}$. & $\begin{array}{c}\text { Boulders and } \\
\text { Gravel }\end{array}$ & $\begin{array}{l}\text { Artificial substrates } \\
\text { and igneous rocks }\end{array}$ & Low & Middle \\
\hline 4 & Muelle & $16^{\circ} 50^{\prime} 56.86^{\prime \prime}$ & $99^{\circ} 54^{\prime} 02.39^{\prime \prime}$ & $60 \mathrm{~m}$. & $\begin{array}{l}\text { Blocks and } \\
\text { Boulders }\end{array}$ & $\begin{array}{l}\text { Metamorphic and } \\
\text { artificial substrates }\end{array}$ & Middle & Middle \\
\hline 5 & Tlacopanocha & $16^{\circ} 50^{\prime} 41.53^{\prime \prime}$ & $99^{\circ} 54 ' 25.02^{\prime \prime}$ & $200 \mathrm{~m}$. & $\begin{array}{c}\text { Blocks and } \\
\text { Gravel }\end{array}$ & $\begin{array}{l}\text { Artificial substrates } \\
\text { and igneous rocks }\end{array}$ & Middle & Middle \\
\hline 6 & Manzanillo & $16^{\circ} 50^{\prime} 27.90^{\prime \prime}$ & $99^{\circ} 54 ' 38.14 "$ & $22.87 \mathrm{~m}$ & $\begin{array}{c}\text { Boulders } \\
\text { and Gravel }\end{array}$ & $\begin{array}{c}\text { Metamorphic and } \\
\text { igneousrocks }\end{array}$ & Low & Low \\
\hline 7 & Enamorados & $16^{\circ} 49^{\prime} 19.34^{\prime \prime}$ & $99^{\circ} 54^{\prime} 07.63^{\prime \prime}$ & $74.80 \mathrm{~m}$. & Massif rocks & Igneousrocks & High & High \\
\hline 8 & Palmitas & $16^{\circ} 49^{\prime} 26.93^{\prime \prime}$ & $99^{\circ} 54^{\prime} 40.88^{\prime \prime}$ & $128 \mathrm{~m}$. & $\begin{array}{l}\text { Massif rocks } \\
\text { and blocks }\end{array}$ & Igneousrocks & High & Middle \\
\hline 9 & Majahua & $16^{\circ} 47^{\prime} 39.46^{\prime \prime}$ & $99^{\circ} 50 ' 28.94^{\prime \prime}$ & $600 \mathrm{~m}$. & $\begin{array}{l}\text { Blocks and } \\
\text { Boulders }\end{array}$ & Metamorphic & High & Low \\
\hline
\end{tabular}

The size composition was examined by measuring the length and width (mm) of the specimens, for which a digital caliper (accuracy $0.01 \mathrm{~mm}$ ) was used and descriptive statistics were obtained (maximum, minimum, average and standard deviation.)

\section{Results}

A total of 97 specimens were tested. It was determined that the Conidae family, which is associated with the rocky intertidal zone of Acapulco, Mexico, was composed of two subfamilies, five genera and five species.

The subfamily PUNCTICULIINAE showed higher species richness, abundance and frequency of occurrence.

This subfamily was composed of four genera and four species. The subfamily CONINAE Fleming, 1822 was composed of one genus and one species. The species showed higher relative abundance was Harmoniconus nux, followed by Gladioconus gladiator (Figure 2 and Table 2). This species had not been reported to the State of Guerrero.

The sites with the highest species richness and abundance were Manzanillo and Majahua.

The species that appeared in most of the sampling sites was $H$. nux, which was found in six of the nine sites, followed by G. gladiator, found at five sites. The other species were presented at a sampling site and were found to be of irregular distribution (Table 2).

The maximum size in length and width were found in Chelyconuspurpurascens (G.B. Sowerby, 1833) (Table 3). The average size in length and width calculated for $H$. nux, was recorded as the lowest, comparing it with other species of cone shells (Table 3 ).

\section{Discussion}

Reports of sites that have different substrate types and depths in the Mexican Pacific Coastand that contain lists 


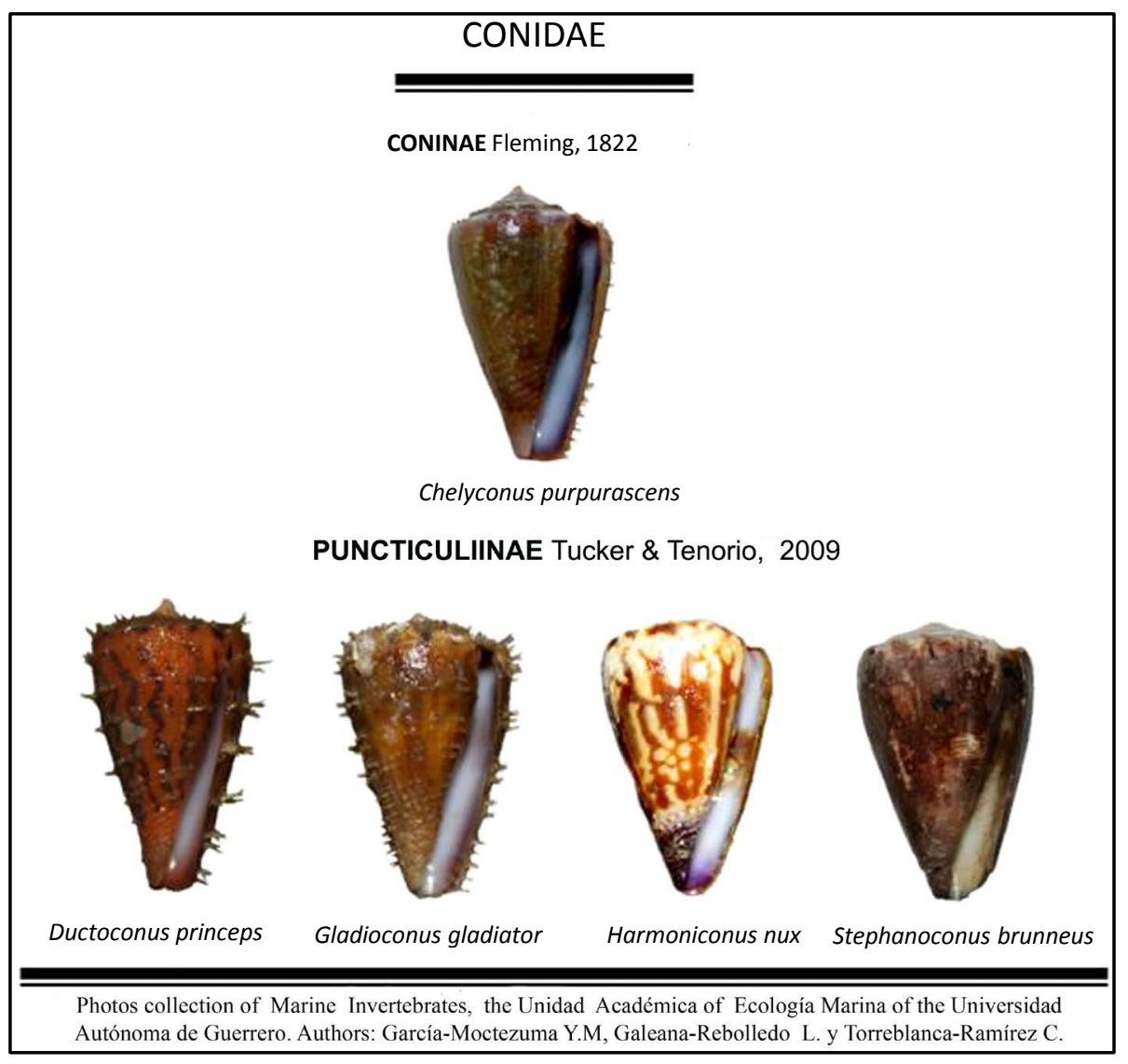

Figure 2. Species richness of the family Conidae in the rocky intertidal of Acapulco, Mexico.

Table 2. Species richness, relative, abundance, abundance at sites and geographical distribution of Conidae family, associated with rocky intertidal in Acapulco, Mexico.

\begin{tabular}{|c|c|c|c|c|c|c|c|c|c|c|c|}
\hline \multirow{2}{*}{ Subfamilies/genus/species } & \multirow{2}{*}{ RA. (\%) } & \multicolumn{9}{|c|}{ SITES } & \multirow[t]{2}{*}{ GD } \\
\hline & & 1 & 2 & 3 & 4 & 5 & 6 & 7 & 8 & 9 & \\
\hline \multicolumn{12}{|l|}{ CONINAE Fleming, 1822} \\
\hline \multicolumn{12}{|l|}{ Chelyconus Mörch,1852 } \\
\hline Chelyconuspurpurascens (G.B. Sowerby, 1833) & 1.03 & & 1 & & & & & & & & I \\
\hline \multicolumn{12}{|l|}{ PUNCTICULIINAE Tucker \& Tenorio, 2009} \\
\hline \multicolumn{12}{|l|}{ Stephanoconus Mörch,1852 } \\
\hline Stephanoconus brunneus (Wood, 1828) & 1.03 & 1 & & & & & & & & & I \\
\hline \multicolumn{12}{|l|}{ Ductoconusda Motta,1991 } \\
\hline Ductoconus princeps (Linnaeus, 1758) & 1.03 & & & & & 1 & & & & & I \\
\hline \multicolumn{12}{|l|}{ Gladioconus Tucker \& Tenorio, 2009} \\
\hline Gladioconus gladiator (Broderip, 1833) & 19.58 & 6 & & & 5 & 5 & 2 & 1 & & & $\mathrm{R}$ \\
\hline \multicolumn{12}{|l|}{ Harmoniconus da Motta, 1991} \\
\hline Harmoniconus nux (Broderip, 1833) & 77.31 & 6 & & 6 & 4 & 45 & & 11 & 3 & & $\mathrm{R}$ \\
\hline
\end{tabular}

RA: Relative Abundance, 1: Majahua, 2: Parque de la Reina, 3: Muelle, 4: Tlacopanocha, 5: Manzanillo, 6: La Angosta, 7: Enamorados, 8: Palmitas, 9: Pie de la Cuesta, GD: Geografical Distribution, A: amplia, R: regular and I: irregular. 
Table 3. Size structure of the species of the family Conidae associated with rocky intertidal of Acapulco, Mexico.

\begin{tabular}{lccccccccc}
\hline \multirow{2}{*}{ Species } & \multicolumn{4}{c}{ Length $(\mathrm{mm})$} & \multicolumn{3}{c}{ Wide (mm) } \\
\cline { 2 - 10 } & Total & Mín. & Máx. & Av. & Sd. & Mín. & Máx. & Av. & Sd. \\
\hline C. purpurascens & 1 & 40.11 & 40.11 & 40.11 & & 22.86 & 22.86 & 22.86 \\
$\begin{array}{l}\text { S. brunneus } \\
\text { D. princeps }\end{array}$ & 1 & 31.4 & 31.4 & 31.4 & & 18.8 & 18.8 & 18.8 \\
G. gladiator & 1 & 31.54 & 31.54 & 31.54 & & 15.43 & 15.43 & 15.43 & \\
$\quad$ H. nux & 79 & 8.16 & 37.12 & 19.46 & 7.65 & 3.76 & 21.18 & 11.2 & 4.34 \\
\hline
\end{tabular}

Min: minimum, Máx: maximum, Av: average and Sd: Standard deviation.

of species of molluscs, which includes the Family Conidae as [9]-[13] reported greater species richness than that found in this investigation. This research coincides with that of the authors of the above mentioned reports in three species: $H$. nux, C. purpurascens and D. princeps.

In reports from different sites in the state of Guerrero, which contain lists of species including the conus [14]-[21], a maximum of four species is reported (H. nux, S. brunneus, C. purpurascensy, D. princeps), which are the same as those found in this investigation. In this study higher species richness was reported, since $G$. gladiator was found, and this species is reported for the first time in Acapulco and the state of Guerrero.

Reference [23], in research where samples from intertidal and subtidal zone were collected and was exclusive to the Conidae family, reported to Tecanatita, Jalisco, the same species that are reported in this study and was in the subtidal zone where they found the highest species richness.

In this research $H$. nux was determined as the most abundant species. The same was reported for different sites of the rocky coast of State of Guerrero and Jalisco by [14]-[21] [23]. In the rocky intertidal zone of Acapulco, G. gladiator was the species ranked second in abundance. This is contrary to what [3] [23] reported, as they say G. gladiator is an occasional or rare species.

Reference [20] reported H. nux as a kind of irregular distribution for the state of Guerrero. They found it in two of the nine sites sampled. This study found that $H$. nux is the species with the widest geographic distribution, followed by G. gladiator. The other species were presented at a sampling site.

In the report [11], they mentions that the $H$. nux is the species that had the highest dominance, the above coincides with the results obtained in this investigation. Regarding sizes, [19] [21] found an average size in length for $H$. nux similar to what was estimated in this study.

To the coast of Jalisco, [22] reports the $H$. nux as the smallest species in length. The minimum size found was $10 \mathrm{~mm}$ and the maximum size of $22 \mathrm{~mm}$. This research also determined this species as the smaller in size and the minimum and maximum length found are similar. The author cited above also reported that the size structure of G. gladiator, is made up of smaller size than C. purpurascens, S. brunneus and D. princeps but greater than those found in $H$. nux. Thesize range of this species found it is 24 to $36 \mathrm{~mm}$ in length and size range of this species found is 24 to $36 \mathrm{~mm}$ in length.

This research coincides with that reported by [22], with respect to the position of G. gladiator in the size structure of Conidae family, but there are differences in the report, the minimum size found for this species, because of that were registered in the rocky intertidal zone, several organisms considerably smaller than reported by [22] as minimum size.

We could not compare the size composition of C. purpurascens, S. brunneus and D. princeps with other reports, because only one specimen we examined, but we agree with [22], in that the larger size was found in $C$. purpurascens.

\section{Conclusions}

Species richness is similar to that reported by exclusive Conidae family studies, carried out at other sites in the transitional Mexican Pacific.

Given the intensive effort and sampling methods, there is a low probability of finding other species Conidae family at rocky intertidal zone of Acapulco. 
Considering that the Conidae family is characterized by low population densities, the abundance of specimens in rocky intertidal Acapulco corresponds to expectations.

The subfamily PUNCTICULIINAE is best represented in species richness and abundance.

$H$. nux and G. gladiator, are the most abundant species and those that had a higher frequency of occurrence, so that they are considered as representative of the family Conidae in the rocky intertidal zone of Acapulco. The other species are considered rare or occasional.

For the first time G. gladiator is reported for the state of Guerrero.

The size structure of the family Conidae found in the rocky intertidal of Acapulco, is similar to what has been reported elsewhere for Transitional Mexican Pacific.

\section{References}

[1] Tait, R.V. and Dipper. F.A. (1998) Elements of Marine Ecology. 4th Edition, Buttrtworth-Heinemann.

[2] Díaz, J.M., Gracia A.C. and Cantera. K.J.R. (2005) Checklist of the Cone Shells (Mollusca: Gastropoda: Neogastropoda. Conidae) of Colombia. Biota Colombiana, 6, 73-85.http://www.redalyc.org/pdf/491/49106105.pdf

[3] Tenorio, M.J., Tucker J.K. and Chaney. H.W. (2012) A Conchologt Iconography. The Families Conilithidae and Conidae. The Cones of the Eastern Pacific. Hackernheim: Conchbooks.

[4] Bandel, K. (1976) Spinning Development and Ecology of Some Higher Neogastropoda from the Caribbean Coast of Colombia (South America). The Veliger, 19, 176-193.

[5] Keen, A.M. (1971) Sea Shells of Tropical West America. 2nd Edition, Stanford, California, EEUU.

[6] Röckel, D., Korn, W. and Kohn. A.J. (1995) Manual of the Living Conidae, Vol. 1 The Indo-Pacific Region Christa Hemmen. Verlag, Wiesbaden, Germany.

[7] Dance, S.P. and Von. R. Cosel. (1977) Das grosse Buch der Meeresmuschelm: Schenecken und Muscheln der Weltmeere, Verlag E. Ulmer, Stuttgart, Germany.

[8] López, S.J. (2004) Técnicas e biología Molecular Aplicadas a la Taxonomía y Filogenia de Moluscos. Spira, 23-33.

[9] Landa-Jaime, V. and Rciniega-Flores. J.A (1998) Macromoluscos bentónicos de fondos blandos de la plataforma continental de Jalisco y Colima, México. México. Ciencias Marinas, 24, 155-167.

[10] Villarroel, M.M., Magaña, M.A., Gómez, C.B., Del Rio, Z.O., Lucio, P.J. and Sánchez, S.J. (2000) Diversidad de moluscos en el litoral rocoso de Michoacán, México. Mexicoa, 2, 54-63.

[11] Zamorano, P., Barrientos-Luján, N.A. and Ramírez-Luna. S. (2008) Malacofauna del infralitoral rocoso de Agua Blanca, Santa Elena Cozoaltepec, Oaxaca. Ciencia y Mar, XII, 19-33. http://www.umar.mx/revistas/36/malacofauna.pdf

[12] Ortiz-Arellano, M.A. and Flores-Campaña, L.M. (2008) Catálogo descriptivo e ilustrado de los moluscos de la zona intermareal de las islas de la bahía de Navachiste, Sinaloa, México. Universidad Autónoma de Sinaloa y Gobierno del Estado de Sinaloa-Consejo Nacional de Ciencia y Tecnología.

[13] Flores R.P., Santiago, C.E., Flores, G.R., García, I.S., Torreblanca, R.C., Galeana, R.L. and Rojas, H.A.A. (2012) Malacofauna de la zona intermareal rocosa de San Pedro Mixtepec y de Sata María Tonameca, Oaxaca, Mexico. Tlamati Sabiduria, 4, 28-34.

[14] Villalpando, E. (1986) Diversidad y zonación de moluscos de Facie rocosa isla de la Roqueta, Acapulco, Gro. Tesis de Licenciatura. Facultad de Ciencias Universidad Nacional Autónoma de México. México, DF.

[15] Salcedo, M.S., Green, G., Gamboa, C.A. and Gómez. P. (1988) Inventario de macroalgas y macroinvertebrados béntico, presentes en áreas rocosas de Zihuatanejo, Gro, Méx. Instituto de Ciencias Del Mar y Limnologia. Universidad Nacional Autónoma de México, 15, 73-96.

[16] Flores-Rodríguez, P., Flores-Garza, R., García-Ibáñez, S. and Valdés-González, A. (2003) Riqueza y diversidad de la malacofauna del mesolitoral rocoso de la Isla la Roqueta, Acapulco, Guerrero, México. Época, 11, 5-14.

[17] Flores, R.P. (2004) Estructura de la comunidad de Moluscos del mesolitoral superior en playas de Facie rocosa del Estado de Guerrero, México. Tesis de Doctorado. Facultad de Ciencias Biológicas. Universidad Autónoma de Nuevo León, Nuevo León.

[18] Torreblanca, R.C. (2010) Análisis de la diversidad y estructura de la comunidad de moluscos del mesolitoral rocoso de Acapulco, Gro., Tesis de Licenciatura. Unidad Académica de Ecología Marina. Universidad Autónoma de Guerrero, Guerrero.

[19] Flores-Garza, R., Torreblanca-Ramírez, C., Flores-Rodríguez, P., Garcia-Ibañez, S., Galeana-Rebolledo, L., ValdésGonzález, A. and Rojas-Herrera, A.A. (2011) Mollusc Community a Rocky Intertidal Zone in Acapulco, México. Biodiversity, 12, 144-153. http://www.tandfonline.com/doi/full/10.1080/14888386.2011.625520\#.UzxKC6gk1dg 
[20] Flores-Rodríguez, P., Flores-Garza, R., García-Ibáñez, S., Valdés-González, A., Violante-González, J., Cortés, E., Galeana-Rebolledo, L. and Torreblanca-Ramírez, C. (2012) Mollusk Species Richness on the Rocky Shores of the State of Guerrero, Mexico, as Affected by Rains and Their Geographical Distribution. Natural Resources, 3, 248-260. http://www.scirp.org/journal/PaperInformation.aspx?PaperID=26293\#.UzxFHKgk1dg

[21] Torreblanca, R.C., Flores, R., Flores, P., García, S., Valdés, A. and Galeana, L. (2012) Gastropodos del intermareal rocoso en Tlacopanocha, Acapulco, México. Tlamati Sabiduría, 4, 47-57.

[22] Landa, J.V. (2013) Bases ecológicas de los caracoles marinos del Género Conus asociados al arrecife coralino de Tenacatita, Jalisco, México. Tesis de Doctorado. Posgrado en Ciencias Biológico Agropecuarias. Universidad Autónoma de Nayarit, Nayarit.

[23] Landa, J.V., Michel, M.J.E., Castillo, V.S.G. and Heimer, C.E.P. (2013) Los caracoles, conos de Tenacatita, productores de venenos con potencial biomédico. Elementos, 90, 41-48. http://www.elementos.buap.mx/num90/pdf/41.pdf

[24] Flores-Garza, R., Galeana-Rebolledo, L., Reyes-Gómez, A., García-Ibáñez, S., Torreblanca-Ramírez, C., Flores-Rodríguez, P. and Valdés, A. (2012) Polyplacophora Species Richness, Composition and Distribution of Its Community Associated with the Intertidal Rocky Substrate in the Marine Priority Region No. 32 in Guerrero, Mexico. Open Journal of Ecology, 2, 192-201. http://www.scirp.org/journal/PaperInformation.aspx?PaperID=24567\#.UzxGnKgk1dg

[25] Mottana, A., Crespi, R. and Liborio, G. (1980) Guía de minerales y rocas, segunda edición. Grijalbo, Barcelona. 